\title{
The Socio-Economic Benefit of the Livestock Traceability System on Communal Beef Farmers in Swaziland
}

Tania Prinsloo

Carina De Villiers

Cheryl M E McCrindle
University of Pretoria, South Africa

tania.prinsloo@up.ac.za

Corresponding author

University of Pretoria, South Africa carina.devilliers@up.ac.za

University of Pretoria, South Africa cheryl.mccrindle@up.ac.za

Swaziland is a small African country that implemented a livestock traceability system to benefit both communal and commercial farmers. The communal farmers are also able to export beef to European countries, markets that were previously unavailable to them, due to the successful implementation of the Swaziland Livestock Information and Traceability System (SLITS). Livestock traceability is briefly explained in the context of the importance of safe food production for human consumption, and a few aspects are highlighted. The traceability system is further explained including its benefit to the rural economy, its role in growing the GDP and the realization of its aims as was initially expected by the Swazi Government. The data collection methods were a document review, a case study and five interviews. We conclude that livestock traceability systems should be more widely adopted by other developing countries as they have a direct effect on the improvement of the socio-economic conditions of the rural poor. Their development and implementation remain very expensive, but Swaziland is an example of a country able to reap the rewards from a commodity that is ample in their country, but scarce globally, leading to wider food sustainability.

Prinsloo, T.,De Villiers, C., McCrindle, C. (2018). The Socio-Economic Benefit of the Livestock Traceability System on Communal Beef Farmers in Swaziland. The Journal of Community Informatics, 14(2), 39--63.

Date submitted: 2017-11-30. Date accepted: 2018-11-22.

Copyright (C), 2018 (the author as stated). Licensed under the Creative Commons AttributionNonCommercial-ShareAlike 2.5. Available at: www.ci-journal.net/index.php/ciej/article/view/1429 


\section{Introduction}

The Millennium Development Goals Report of 2015 had eight goals, the first of which was to "eradicate extreme hunger and poverty" (United Nations, 2015). If rural poverty is reduced, an overall poverty reduction can be achieved in a country (World Bank, 2007). Many countries in Sub-Saharan Africa experience high levels of poverty and hunger, stagnant agricultural production and rising food shortages (McGuire, 2015; Wik, Pingali, \& Broca, 2008). The agricultural sector in the region is tasked with feeding more than 7.3 billion people in 2015 (Population Reference Bureau, 2015), a number estimated to reach 9.19 billion in 2050 (Thornton, Jones, Ericksen, \& Challinor, 2011). Communal livestock farming is particularly important for food security in SubSaharan Africa, and Swaziland is a good example of how improved livestock management could improve rural livelihoods (Prinsloo, 2017). Traceable food products are required for European markets. Countries with undervalued currencies and reliable traceability systems can become preferred suppliers (Martinez \& Poole, 2004). Developing countries could position themselves to exploit this strategic opportunity to grow their economy by exporting greater quantities of beef (Sodano \& Verneau, 2004).

Swaziland is a small landlocked country in the southern part of Sub-Saharan Africa and its economy is strongly linked to cattle farming (Prinsloo, 2017). In Swaziland, communal farmers are paid better prices for cattle slaughtered for export (Prinsloo, 2017), so there could be a direct effect on food security and the rural economy if traceability is used to increase beef exports. This article will discuss how Swaziland successfully implemented their livestock traceability system and are now benefitting from international trade. The methods were to conduct a document review of the impact of cattle farming on the socioeconomics in Swaziland, a case study of the implementation of the Swaziland Livestock Information and Traceability System (SLITS) in communal cattle farms; and interviews with key informants who were roleplayers facilitating SLITS.

\section{Livestock Traceability}

Traceability is defined as "the ability to track their movements, proper identification of premises, and recording of this information in appropriate register" (Vallett, 2013). The movement of meat along a food chain follows a "farm-to-fork" traceability approach (Brown \& Van der Ouderaa, 2007; Duffy, Lynch, \& Cagney, 2008; Mogensen et al., 2015; Weiss, 2012). The components that form part of a successful traceability system are summarized in Figure 1: 


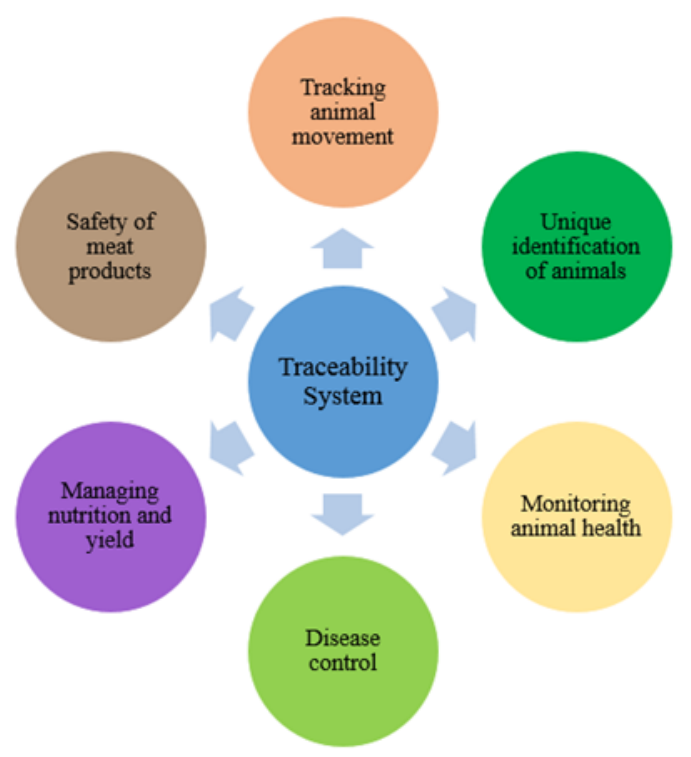

Figure 1: The main components of a Livestock Traceability System (Prinsloo, 2017)

\section{Tracking animal movement}

To illustrate the complexity of controlling animal movement, an example is given from the Namibian Livestock Identification and Traceability System (NamLITS). This system has three ways of capturing animal movements in its database: the farm-to-farm movement, the farm-to-auction movement and the farm-to-abattoir movement. The different procedures are explained in Figures 2, 3 and 4.

\section{Farm-to-farm movement}

Farm-to-farm movement (Figure 2) entails the following:

1. The farm of origin verifies the tags against the permits when the cattle are being loaded.

2. The cattle, permits and departure registers are sent to their destination farm.

3. The destination farm verifies the tags when the cattle are being off-loaded.

4. The destination farm then sends back the permits and registers.

5. The farm of origin sends the permits and departure register to the Director of Veterinary Services (DVS).

6. The destination farm sends the permit, arrival and departure registers to DVS.

The tracking of animal movements is very important to comply with the $90 / 40$ day rule. This rule implies that an animal cannot be slaughtered within 90 days after entering the country, or 40 days since its last move from farm-to-farm, farm-to-auction or farm-toabattoir. 


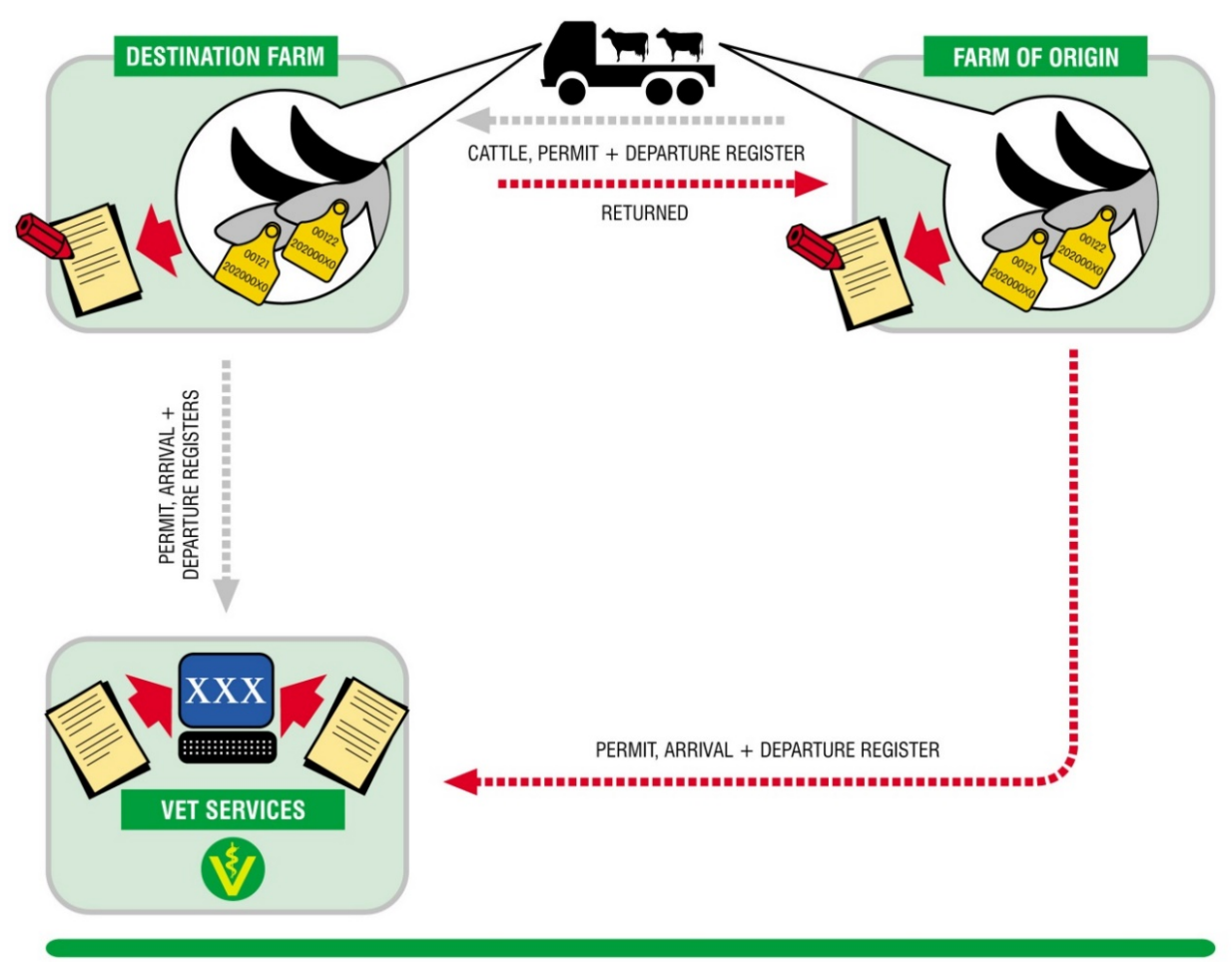

Figure 2: The process of moving an animal from one farm to the next with a movement permit (Adopted from Engelbrecht (2012)

\section{Farm-to-auction movement}

Figure 3 illustrates farm-to-auction movement. Livestock are often sold on auctions in Namibia. The procedure to move cattle from a farm to an auction works as follows:

1. The farm of origin verifies the tags against the permits when the cattle are loaded at the original farm.

2. The cattle, permits and departure registers are sent to the auction.

3. At the auction, the tags are verified when the cattle are being off-loaded.

4. From the auction, the cattle, permits and departure registers are sent to the buyer of the cattle.

5. The farm of origin sends the permits and departure register to the DVS.

6. The buyer sends the permit, arrival and departure registers to the DVS.

The 90/40 day rule applies to the movement of cattle from the original farm to the buyer. 


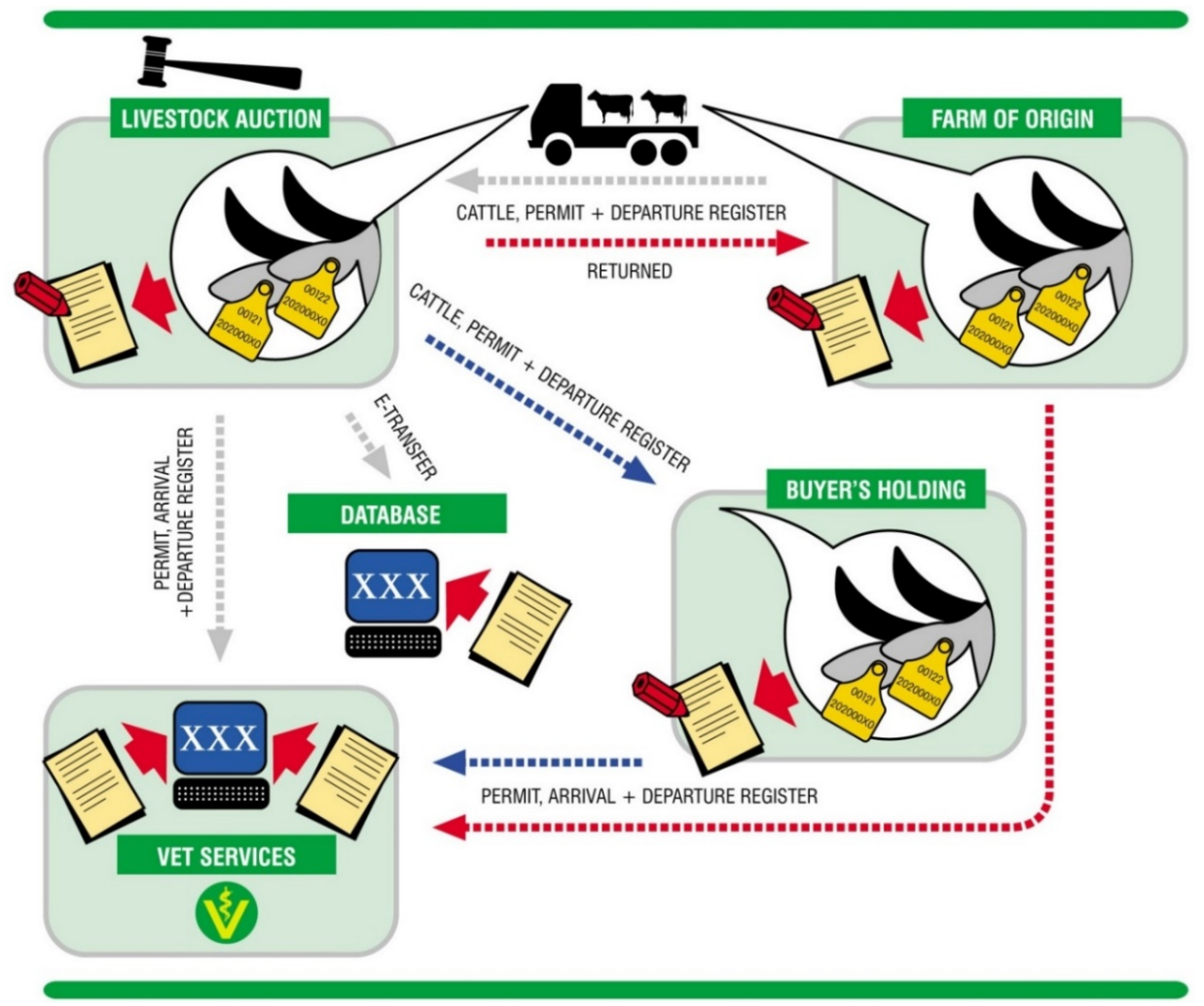

Figure 3. Farm-to-auction movement of cattle, illustrating the detailed documentation required (Adopted from Engelbrecht (2012))

Farm-to-abattoir movement

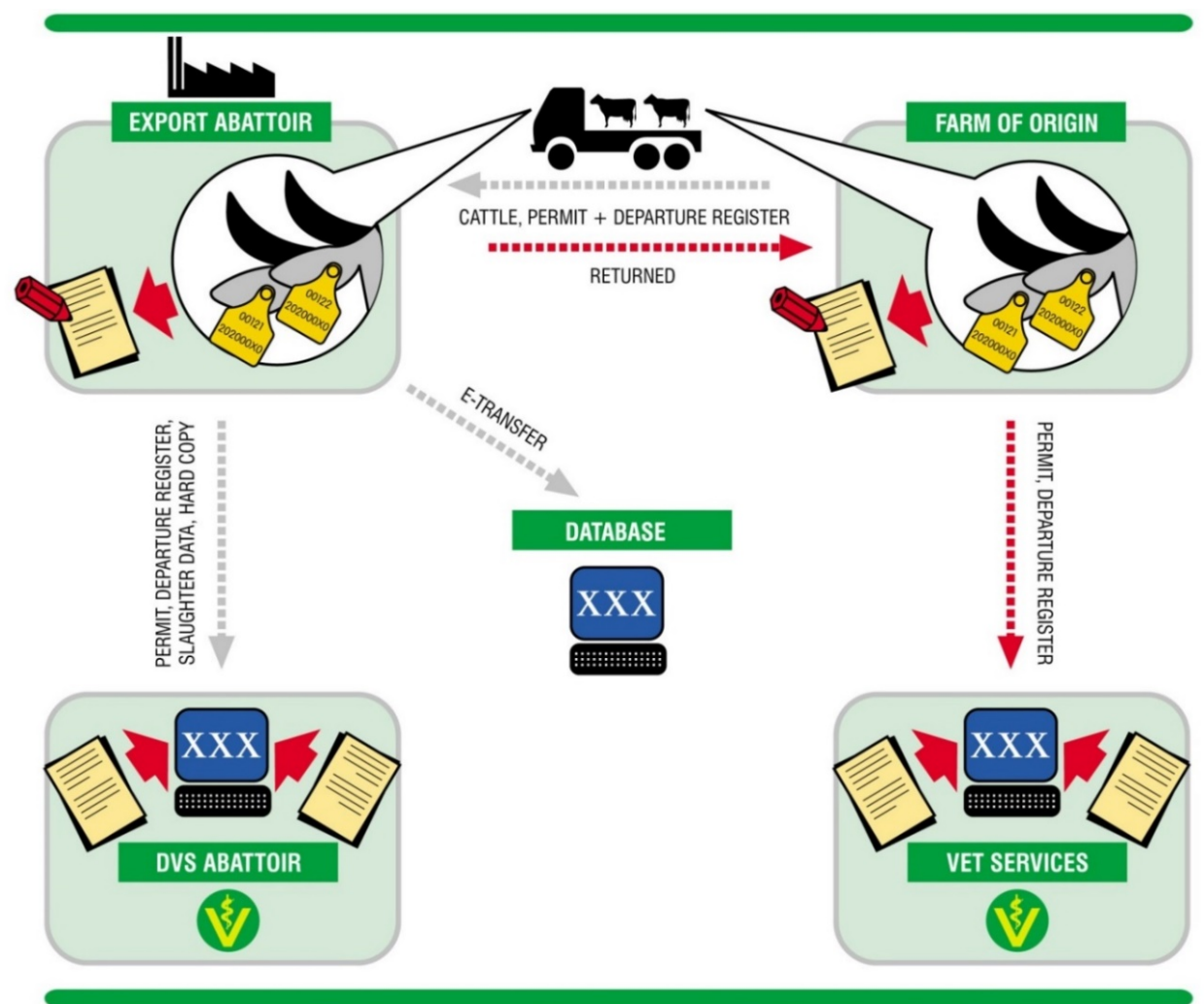


Figure 4: Farm-to-abattoir movement of cattle, and its documentation required (Adopted from Engelbrecht (2012)

Note: DVS Abattoir $=$ Director of Veterinary Services Abattoir

To move cattle from the original farm to the abattoir (Figure 4) involves the following:

1. The farm of origin verifies the tags against the permits when the cattle are loaded at the original farm.

2. The cattle, permits and departure registers are sent to the export abattoir.

3. The export abattoir verifies the tags when the cattle are being off-loaded.

4. The destination farm then sends the permit and departure register to Veterinary Services.

5. The export abattoir sends the details to the NamLITS database.

6. The export abattoir sends the permit, departure register and slaughter data hard copies to the DVS.

Everything, including adhering to the $90 / 40$ day rule, is captured on the database.

Figures 2, 3 and 4 illustrate the overall comprehensive, complex paper trail and database that must record all the movements of animals. It is not a simple task, and the process must still carry on after the animal has been slaughtered. Complete traceability of meat products as the animal is slaughtered in the abattoir entails handling one carcass at a time, putting all the meat into a single container, and then transporting the container to "single-carcass lots" (Smith et al., 2008), where bar-coded tags are placed on all retail cuts. The importer and consumer can trace the animal movement, as well as the movement of different meat cuts. Keeping track of the movement of meat is often referred to as the "farm-to-fork" traceability approach (Brown and Van der Ouderaa, 2007, Duffy et al., 2008, Weiss, 2012, Mogensen et al., 2015).

\section{Unique identification of animals}

All animals in a livestock traceability system need to be uniquely identified. The animal's owner must also be identifiable with either a unique farm identifier, or area identifier such as a dip tank. The various ways of identifying a farmer or region differ among traceability systems. In Swaziland, the dip tank area is indicated on the yellow, plastic ear-tag, just below the Swazi shield, followed by the animal's unique number for the given dip tank. Cattle are also branded on the hind leg, where the animal is branded with the specific dip tank number. If the animal is moved from one dip tank to another, it is branded on the other hind leg, and then on the shoulders, if moved again. If change of ownership occurs, the data is transferred to the new owner. Figure 5 is an example of what a Swazi ear-tag looks like. 


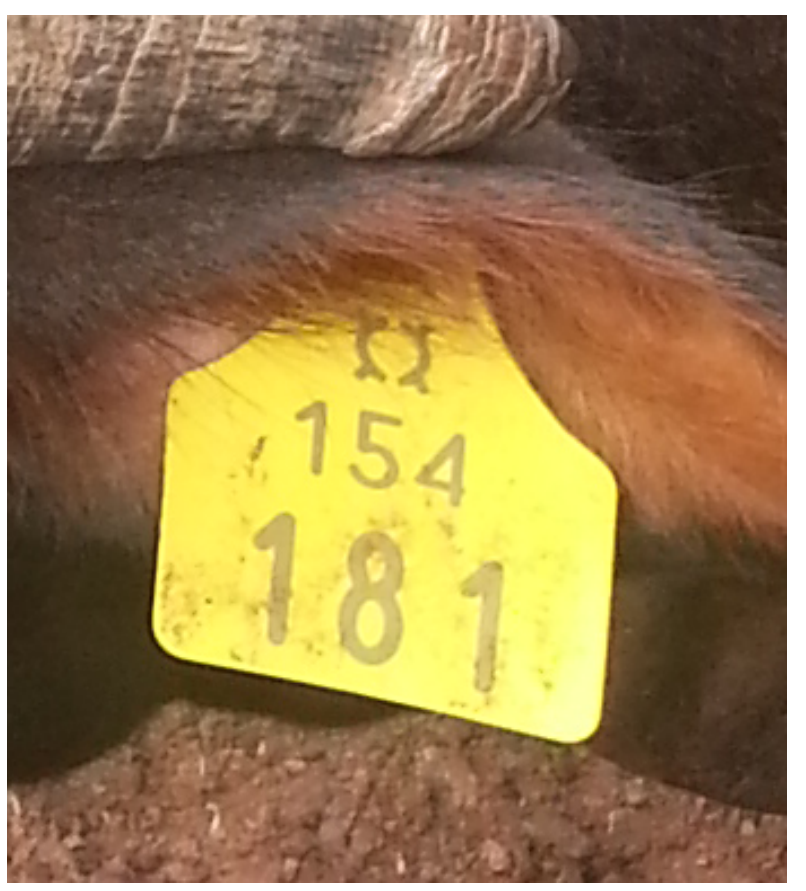

Figure 5: An example of a Swazi ear-tag

\section{Monitoring animal health}

The cattle need to be inspected regularly for any symptoms of disease or outbreaks that might have occurred in the region. The regular dipping events in Swaziland are documented by capturing the animal's details in the register and transferring them to the central database. If any animal is not at the regular dipping event, the reason for the absence needs to be investigated and documented. If an animal died, the details of the death is captured and the animal is deregistered on SLITS (Mdluli, 2012).

\section{Disease control}

Disease outbreaks cannot be predicted, and even if they have been identified and contained, there are different ways of addressing the outbreak. Worldwide, the following four ways of controlling diseases have been implemented (Scoones and Wolmer, 2003):

\section{Export zones with vaccination}

Cattle are vaccinated twice a year in areas where buffalo are present. Animals are contained by fences that restrict movements (Vosloo et al., 2002). Further measures can include veterinary health inspections, veterinary supervision of high-risk areas to monitor diseases and frequent examination of animals (Bengis et al., 2002).

\section{Compartmentalisation}

Cattle need to be kept in mini-zone areas, typically farm fences or game fences. Containing animals is difficult in the Northern Communal Areas as cattle graze freely. Another important part of compartmentalisation is the successful implementation of a 
livestock traceability system, as is currently in place in Namibia, with NamLITS becoming operational in 2005 .

\section{Commodity-based trade}

The focus is not on the infected animal, but rather ensuring that the final product is safe for human consumption. In cases of livestock with foot-and-mouth disease deboned beef and matured beef pose no threat to human health (Rich and Perry, 2011). Technological modernisation and market development can strengthen this movement (Scoones and Wolmer, 2006).

\section{Managing beef supply for local trade}

Beef still needs to adhere to food safety standards and a steady supply of animals for local markets needs to be ensured.

The different ways of addressing disease outbreaks are important because not all diseases impact humans as one might anticipate. Consumers should be aware of the risks. Managing beef supply for local trade can be done at a relatively low cost. As one moves to compartmentalisation and export zones with vaccination, the cost of disease control increases dramatically because of the high value of exporting to countries in the EU or Norway (Scoones and Wolmer, 2003). If disease outbreaks can be anticipated, one can address the threat in the way grazing of the animals is managed and assist in managing nutrition and yield. The animals have to be fed with food and feed products that adhere to international legislation (Aung and Chang, 2014). Only certain antibiotics are allowed and no growth promotors (Toldrá and Reig, 2006).

\section{Entry to new export markets}

Importers should keep track of the imported meat, until finally reaching the overseas consumer (SAFA, 2003) throughout all stages, as is illustrated in Figure 6. The red meat value chain should have traceability throughout, but the one area where traceability can play a big role, is the import/export market, specifically the export market in this study. For the export market to grow, a holistic farm management system needs to be incorporated.

In Figure 7, an example is given of a typical communal family farm system. Low family income, deteriorating soil quality and excessive work load are identified as three of the main areas of concern in this type of farming method (Dogliotti et al., 2014). 


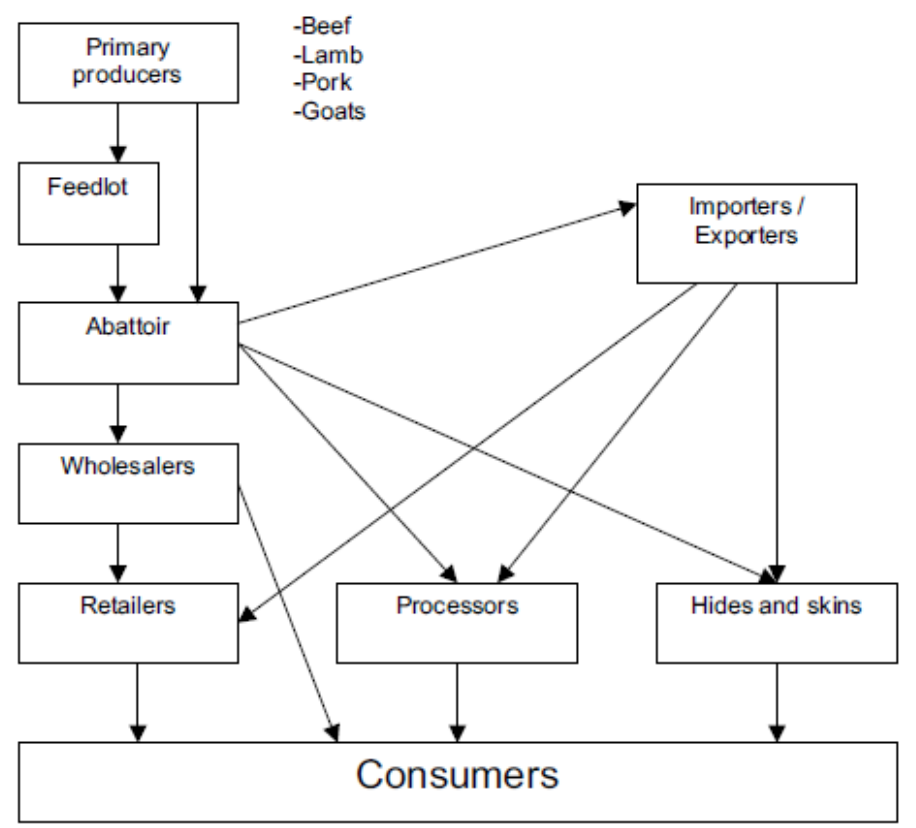

Figure 6: The red meat value chain (Adopted from SAFA (2003))

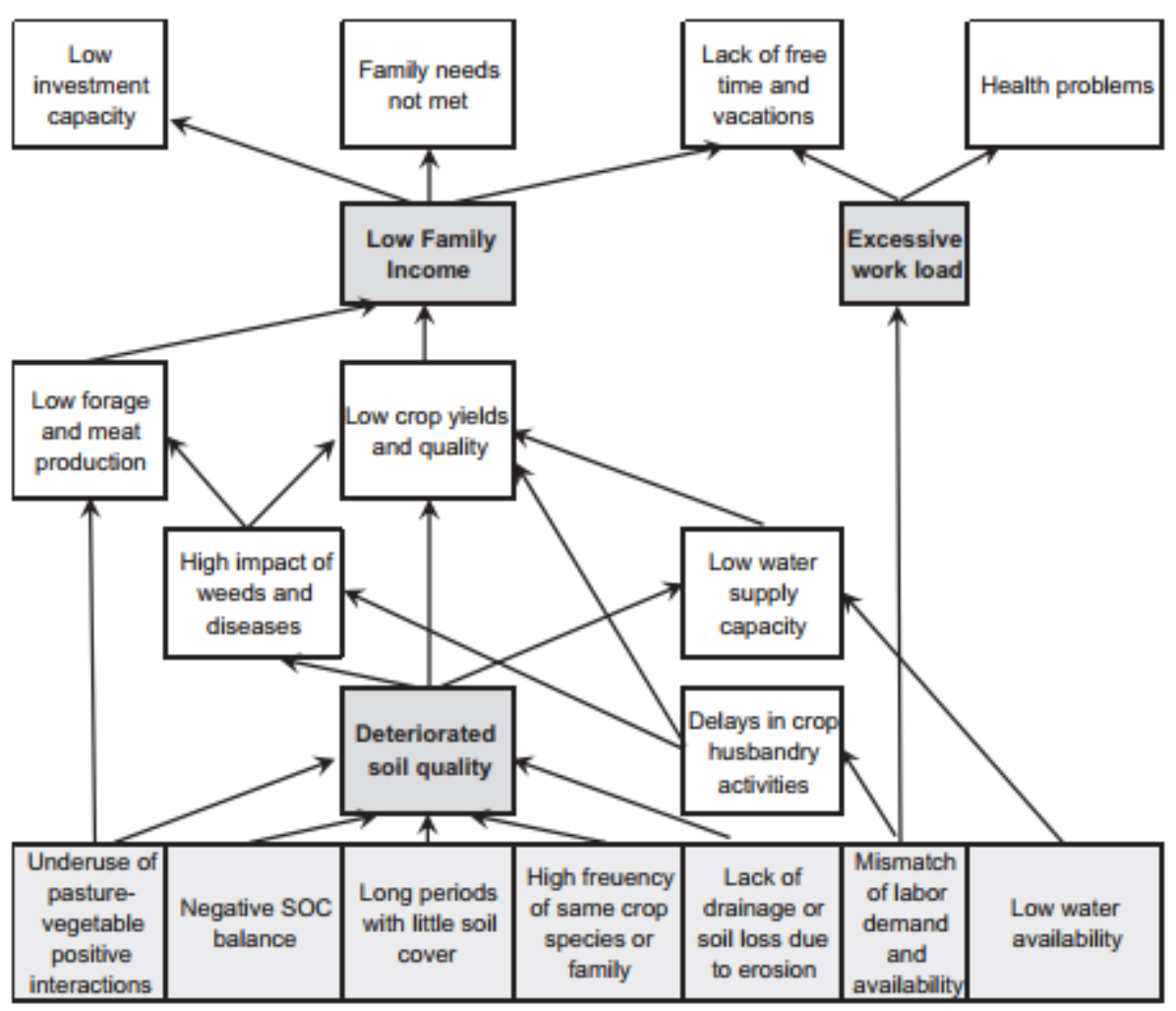

Figure 7: Problem tree summarising typical difficulties with a family farm system (Adopted from Dogliotti et al. (2014) 
If one is to, however, adopt a better strategy, one can identify how improved inputs will lead to better outputs (Van Zyl et al., 2008). A simple example will be if a communal farmer sells his/her cattle at a higher price as a result of traceability, the level of income of the family will rise with every animal sold. In turn, this allows the farmer to buy more animals and then sell fewer animals. With more cattle, the farmer's herd is growing, allowing the farmer to sell more at a later stage when cattle are an optimal age to enable him/her to get even more money per individual animal. Suddenly, the farmer can plough back money into the farm, buying better feed, enabling to herd more cattle, even in winter times when the number of cattle per hectare decreases compared to summer months. The entire red meat value chain grows, creating employment opportunities throughout, as more cattle need to be transported to feedlots and abattoirs, more people are needed to slaughter animals and the farmer can also employ more farm workers, lessening the work load on the family members, improving living conditions by stimulating the rural economy. There are more opportunities for entrepreneurs and the country sees an overall increase in their GDP.

\section{Traceability Legislation}

To be able to access any European meat export market, there are a number of laws and ISO standards that need to be adhered to:

- The General Food Law forms part of the European mandatory legislation and outlines the general principles and requirements of food law. It further provides the procedures in matter of food safety, and among other things, the implementation of traceability systems in the food and feed supply chains in Europe (European Commission, 2002).

- ISO 22000:2005 specifies requirements for a food safety management system where an organisation in the food chain needs to demonstrate its ability to control food safety hazards in order to ensure that food is safe at the time of human consumption (ISO 22000:2005).

- ISO 22005:2007 gives the principles and specifies the basic requirements for the design and implementation of a feed and food traceability system. It can be applied by an organisation operating at any step in the feed and food chain (ISO/TS 22003:2007).

- CAC/GL 60 - 2006. Codex principles for Traceability/Product Tracing as a tool within a Food Inspection and Certification System. This document elaborates a set of principles to assist competent authorities in utilising traceability/product tracing as a tool within their food inspection and certification system (European Commission, 2006).

- Other legislation that include the Technical Barriers to Trade (TBT), the Global Partnership for Good Agricultural Practice (GLOBALGAP) and the Global Food Safety Initiative (GFSI). 
SLITS complies with all the requirements above and the traceable meat can be exported worldwide.

\section{Research Design}

\section{Research Questions}

The main research question is: How would the introduction of a traceability system stimulate the rural economy and benefit communal farmers in Swaziland?

The secondary research questions are:

1. Why are communal farmers important in growing the country's GDP?

2. How does the current political system allow communal farmers to benefit from traceability?

3. How does the introduction of the traceability system realise the aim of the Government of the Kingdom of Swaziland's goals at set out in the project's inception phase?

\section{Qualitative Data Collection Methods}

\section{Document Review}

Traceability in Swaziland is a contemporary theme. One can find scholarly literature about traceability, and its application to other countries, both developed and developing (Leitgeb, Funes-Monzote, Kummer, and Vogl, 2011; Loureiro and Umberger, 2007; Marumo and Monkhei , 2009; Roosen, Lusk, and Fox, 2003), but one needs news articles, policy documents, websites containing new facts and figures and other official documents as additional reference material.

\section{An In-depth Case Study}

Yin (1994) explains that case study research is "an empirical enquiry that investigates a contemporary phenomenon within its real-life context". It also relies on multiple sources of evidence (Benbasat, 1984; Bonoma, 1985; Yin, 1994), and Kaplan \& Maxwell (2005). Yin (2013) believes that these multiple sources of evidence should come from relevant current and archived documents, interviews, observations and physical artefacts.

The authors build a strong case study around communal farmers in Swaziland with four visits to Swaziland, starting in December 2012 and concluding in October 2015. During that time observations took place, interviews were conducted with key stakeholders of the project, documents were obtained and pamphlets were gathered. The observations provided the researcher with the "inner experiences" of the communal farmers, their normal every-day activities, and enabled her to determine how "meanings are formed", to "discover, rather than test variables" (Corbin \& Strauss, 2008). The observations were exploratory and descriptive. 


\section{Personal Interviews}

Five semi-structured interviews were conducted transcribed. The two key decisionmakers in the implementation of SLITS were interviewed, as well as a government official who manages a government farm. The users of the traceability systems and the veterinary assistants in Swaziland were also interviewed to capture their experiences in terms of the usage of SLITS. Communal farmers were not interviewed, as they were in remote areas, often inaccessible. Finally, one representative of the Meat Industries of Swaziland as well as the project manager of SLITS, were interviewed.

All interviews were conducted by the researchers and recorded as qualitative data. The participants were in no way influenced to answer in a specific way and they did not receive any incentives to participate. They also signed a consent form before each interview. The level of complexity of the interviews differed significantly, with the experts in their fields providing detailed information, whereas the veterinary assistants simply explained their working conditions and experiences in the field.

Table 1. A summary of the participants who were interviewed as part of the data collection process

\begin{tabular}{|l|l|}
\hline $\begin{array}{c}\text { Participants in the } \\
\text { interviews }\end{array}$ & \multicolumn{1}{c|}{ Relevance to the study } \\
\hline Participant 1 & $\begin{array}{l}\text { One of the key decision-makers in the implementation of } \\
\text { SLITS }\end{array}$ \\
\hline Participant 2 & $\begin{array}{l}\text { One of the key decision-makers in the implementation of } \\
\text { SLITS }\end{array}$ \\
\hline Participant 3 & $\begin{array}{l}\text { A commercial farmer farming for the Swazi government, and } \\
\text { also an owner of a number of cattle grazing on communal land }\end{array}$ \\
\hline Participant 4 & A Swazi veterinary assistant \\
\hline Participant 5 & A Swazi veterinary assistant \\
\hline Participant 6 & A Swazi veterinary assistant \\
\hline Participant 7 & A representative of the Meat Industries of Swaziland \\
\hline Participant 8 & The project manager of SLITS \\
\hline
\end{tabular}

\section{Findings}

The findings are discussed in three sections, first the document review, second the case study and third the interviews.

\section{Document Review Findings}

The Kingdom of Swaziland 
Swaziland is a small, poor country in Southern Africa, where one of its key commodities is livestock and livestock sales. Cattle play an important role in both the macro and micro level in the economy and also have an important social role. Swaziland has a dual system of land tenure - Swazi National Land (SNL) and Title Deed Land (TDL). The SNL is held in trust by the king, (Central Bank of Swaziland, 2016), and provides land for approximately $84 \%$ of the poor in rural areas (The International Fund for Agricultural Development, 2013). There are four administrative regions: Manzini, Hhohho, Shiseweni and Lubombo, each with a political head appointed by the king. Parallel to government is the traditional system with the king and his traditional advisors and 55 sub-regional districts with traditional chiefs (Encyclopedia of the Nations, 2016).

\section{Swaziland's Economic Outlook}

Swaziland has a small economy, with a Gross Domestic Product (GDP) of only about USD 4.1 billion. The currency used is Emalangeni (SZL), which is linked to the stronger South African Rand (Vandome, Vines, \& Weimer, 2013). Its primary economic sectors are agriculture, forestry and mining. Swaziland is not a major role-player in the Southern African Development Community (SADC).

\section{Swaziland's Social Conditions}

The Swazis speak mainly English, the official language and siSwati, the native language. According to the website Countries and their Cultures (2016), there is a clear distinction between rural and urban citizens, where the knowledge of English marks status and education. Swazis value their sons more highly than their daughters and have a traditional patriarchal system. Children are seen as essential in a marriage, but only men can inherit, therefore rural TDL ownership remains a challenge for women, as traditional chiefs only give land to male citizens (Dlamini-Ndwandwe, 2011). Men are also the only ones allowed to herd cattle, although cattle ownership is common among women.

The number of cattle owned is an indicator of economic status. Swazis are proud of their traditions and cultures. Figure 8 shows a photograph of a Swazi dance being performed in their traditional dress, with some of the clothing and shields made of leather from cattle skins: 


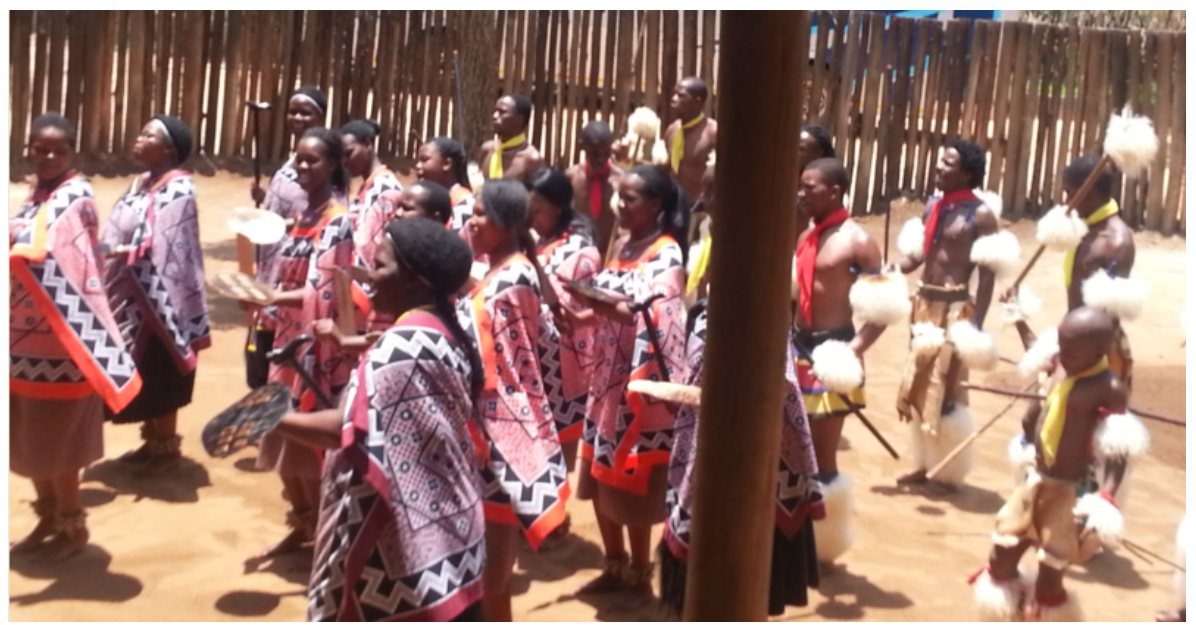

Figure 8: A traditional Swazi dance

\section{Case Study Findings}

Swaziland started ear-tagging communal farmers' cattle in 2012, free of charge, and captured all livestock in a centralized, electronic database called SLITS (Mdluli, 2012). During the inception phase, clear goals had already been set, linked to the anticipated benefits from SLITS. These were to:

1. Improve access to markets of livestock and livestock products;

2. Assist in the recovery and identification of stolen and strayed animals;

3. Assist in the reduction of stock theft and cross border cattle rustling;

4. Assist in disputes over animal ownership among farmers;

5. Assist in rapid containment of animal diseases in the case of outbreaks;

6. Assist in production management; and

7. Improved efficiency of government controlled movement permits. (The Government of the Kingdom of Swaziland, 2012)

A broad analysis of Swaziland and SLITS is necessary to appreciate the scope of the project fully.

SLITS started in August 2012, and by December of the same year, SLITS had been rolled-out in its pilot phase, with initial training in the form of train-the-trainer given to a small group of veterinary assistants, who in turn shared their new knowledge with other veterinary assistants at the regional offices. The first visit to Swaziland took place from 12 to 14 December 2012, and included experiencing a livestock dipping event in Nkonkwane, a small rural area close to Manzini. Three subsequent visits took place up to September 2015. It was soon evident that SLITS was not only gaining momentum but also proving to remain sustainable.

SLITS is a system that enables users to identify and trace every individual animal in Swaziland. The Veterinary Offices identified a need to computerize their databases to ensure the registration, movement, animal health and branding of cattle as stipulated on the "The Government of the Kingdom of Swaziland" website. As part of the 
identification of the cattle within the SLITS system, all communal farmers' animals have been ear-tagged, a project that started in March 2012. It is now much easier for the kraal (native village community) owners and government to keep a record of all animals. Communal farmers' animals graze freely in the SNL areas and there are no fences to keep animals apart. The animals have ear-tags, one big yellow tag in the left ear and a smaller yellow round tag in the right ear.

Veterinary assistants of the Veterinary Services oversee all dipping events and capture the detail of the event on SLITS. This simplifies the movement permits of the animals, and controls the outbreak of any disease. In summer cattle are dipped every 14 days in the drier areas, and once a week in the wetter Lowveld. In winter dipping occurs from 14 up to 28 days. Figures obtained from the Swazi Meat Industries (SMI), the export abattoir, showed a growing trend in beef exports until 2013, with a decline in 2014, believed to be directly linked to the implementation of SLITS. The reason for the decline in 2014 was that not all animals' details were captured on SLITS at the beginning of 2014, therefore the animals could not be sold to the SMI. It was seen as the teething-phase of the SLITS implementation (Mduli, 2014). Almost all Swazi livestock have been captured on SLITS following the initial problems and the numbers have increased since.

The annual beef quota for the EU market is a maximum of 3,600 tons for boneless meat (Cabrera et al., 2010). Without SLITS, all exports to the EU would have been banned, leading to a significant loss in exports for the country as a whole. The high mortality rate of 2015 is because of the persisting drought, as is illustrated in Figure 9.

\begin{tabular}{|l|r|r|r|r|r|}
\hline Item & 2011 & 2012 & 2013 & $2014^{*}$ & $\mathbf{2 0 1 5 \#}$ \\
\hline Total Population & 616,459 & 633,954 & 627,486 & 620,032 & 594,240 \\
\hline Total Slaughers & 44,811 & 46,218 & 56,582 & 50,041 & 61,258 \\
\hline Deaths & 27,417 & 37,341 & 35,096 & 38,899 & 57,796 \\
\hline Mortality Rate & 4.5 & 5.9 & 5.6 & 6.3 & 9.7 \\
\hline
\end{tabular}

Figure 9: Cattle purchased for slaughter between 2009 and 2016 (Created from data obtained by Williams, 2017)

SLITS - 2nd Quarter of 2017

Table 2: Current information on SLITS (Own research)

\begin{tabular}{|l|l|}
\hline Metric & Count \\
\hline Number of SLITS system users & 353 \\
\hline Number of active livestock keepers & 80000 \\
\hline Total number of cattle in the SLITS database & 780000 \\
\hline Number of living cattle in the SLITS database & 620000 \\
\hline Number of dip tanks & 812 \\
\hline
\end{tabular}




\begin{tabular}{|l|l|}
\hline Metric & Count \\
\hline Number of kraals & 60000 \\
\hline
\end{tabular}

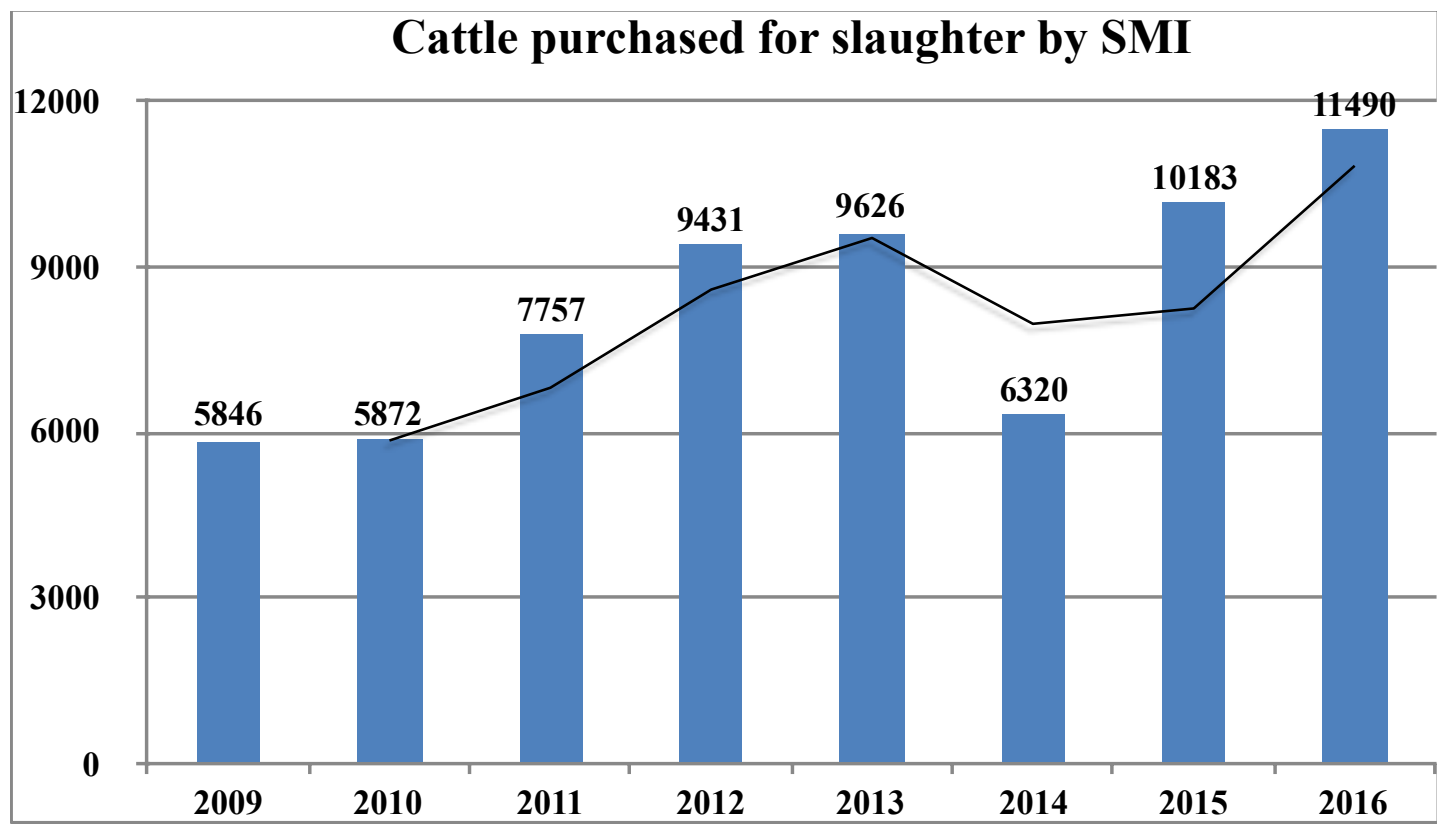

Figure 10: Swaziland livestock cattle production (Adopted from the Central Bank of Swaziland (2016)

\section{Interview Findings}

For data collection, five interviews were conducted over a period of four years. The interview questions show the progression of SLITS, from being introduced to the farmers up to full implementation. This section highlights some of the questions, the main contributions made by the participants and the implications of the responses for SLITS.

The first interview was conducted at the beginning of the project, before it became mandatory to use SLITS. The main decision-makers were interviewed and the interview lasted for 45 minutes. The main findings recorded in that interview are discussed below:

\section{Discussion of Interview 1}

During the first interview, it was established that the new electronic database enables users to move away from a paper-based system, where the animal and the owner's details are centrally stored. Service delivery has improved, with a more efficient and effective system, able to assist in disease control. In terms of ownership, cattle are no longer identifiable only by specific markings on the body, such as white with black spots. Every animal is now given a unique number, enabling the owner to trace it if it 
should stray, and to determine which specific cow gave birth to that animal. The system does not, however, provide the paternity.

SLITS also ensures better service delivery. One no longer has to go to the main offices to arrange change of ownership before going to the dip tank; it can now be done directly at the dip tank, simplifying the process significantly for the farmer. The expectation is to attract younger people to the farming industry by incorporating technology and improving rural livelihoods.

Commercial farmers used their own system in the past, where a farmer would have a brand mark and apply that mark to all his/her animals. The branding was not standardised, making it difficult to audit. If a stray animal needed to be identified, a photograph of the brand was taken, and then compared to the brands in the register kept at the offices of the veterinary assistants. Only the owner of the animal was identified, not the individual animal. This system has now changed, and it has become mandatory that every animal, whether it belongs to a commercial or communal farmer, is uniquely branded by a number, and the number is linked to the electronic database, with a full record of the animal. The animal is typically branded on the left hind leg. Figure 11 is an example of such a brand.

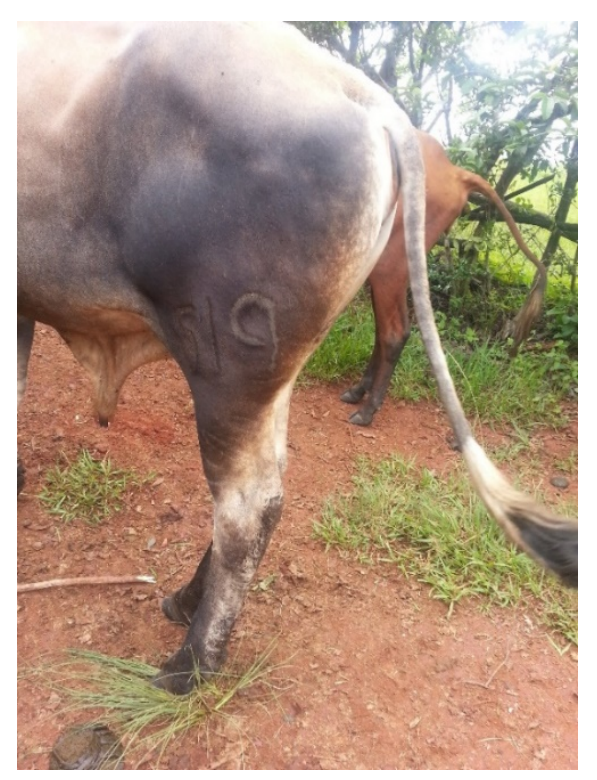

Figure 11. An example of an animal branded with a unique number

SLITS makes identification of animals accurate and current, assisting in diminishing animal theft and rustling, controlling and containing disease outbreaks, and simplifying the issuing of movement permits. It assists the Swazi police in cases where animal ownership needs to be proved, specifically in cases where an animal is involved in an accident. The animals are not kept in camps that are fenced, but graze freely, even on the side of main roads, sometimes leading to accidents where animals are involved. The 
information that is readily available to the police force is an unintended but valuable benefit. SLITS also enables not only commercial farmers, but also communal farmers to export meat, as all animals now meet traceability requirements. Swaziland exports beef mainly to Norway, Switzerland and other EU countries, but will open other markets, including the United States of America and Japan.

\section{Discussion of Interview 2}

The second interview was with one of Swaziland's commercial farmers to determine the farmers' experiences with and feelings regarding SLITS. Commercial farmers farm on government-owned land, but also own their own cattle, grazing freely on communal land. The interview took place on 11 July 2013. The interview lasted for 60 minutes and below is a shortened version of the interview, only highlighting the most important aspects:

In this interview, the breeding season of cattle was discussed to identify periods of calving and weaning, as well as the role of the feedlot. At the feedlot, the animals are fattened, and go either to the Swazi Meat Industries, or to local abattoirs to be slaughtered and sold at butcheries in Swaziland. The commercial farmers also supply meat to the indigenous Swazis. Commercial farmers sell their cattle to the SMI, and they then export whatever meat they have available. Legislation prohibits the SMI to export any meat or meat-products without full traceability of each animal. Employees on the commercial farm own a small number of cattle. It is important for a Swazi to own cattle, as they have a system in place, called lobola. If a young man wants to marry, he has to provide his bride-to-be's family with a certain number of cattle. It was further established that a large number of cattle sent to the feed lot by the farm is bought from local communal farmers. The advantage is that they bring their animals themselves, the commercial farmers weigh the animals, and calculate the price, which the farmers then receive in cash, without having to wait two weeks to be paid by the Swazi Meat Industries.

\section{Discussion of Interview 3}

The third interview took place at one of the veterinary assistants' offices, where they shared some of their experiences of working with SLITS. The interview took place on 12 July 2013. The veterinary assistants talked in great length of their working environments and of their experiences of SLITS and the interview lasted 90 minutes, with a summary given below:

During interview 3, the challenges of cattle rustling were explained. Swaziland struggles with cattle rustling, and one of the benefits of SLITS is that it makes it possible to identify the owner, not only in Swaziland, but in neighboring South Africa and Mozambique. The police find the system very useful in this regard.

Another important discussion was about educating communal farmers to sell their cattle at an optimal age. Communal farmers tend to want to hold onto their younger animals, participant 4 explains, and prefer to sell the older animals to the Swazi Meat Industries 
for slaughter. The meat is then less tender, and the farmers are not paid much for the older animals. The veterinary assistants have advised the farmers to sell the younger animals, but there is still work to be done in educating the farmers. It takes time to bring about a culture change. Communal farmers typically sell animals just before Christmas to provide for the festive season and the start of a new school year for the children, and in April before Easter. The best time to sell is actually in October, as the newly born calves are then at an optimal age to be sent to the feedlots. Except for certain individuals who sell for profit, the cattle are sold mainly to support families during times of family event, for example cattle are slaughtered when there is a funeral, and other times when they need money for school fees and clothing. The most common months are December and April.

The usefulness of SLITS was also discussed, with the veterinary assistants who capture all the information on a Friday at the veterinary offices. Photographs of the capturing process is shown below in Figure 12.

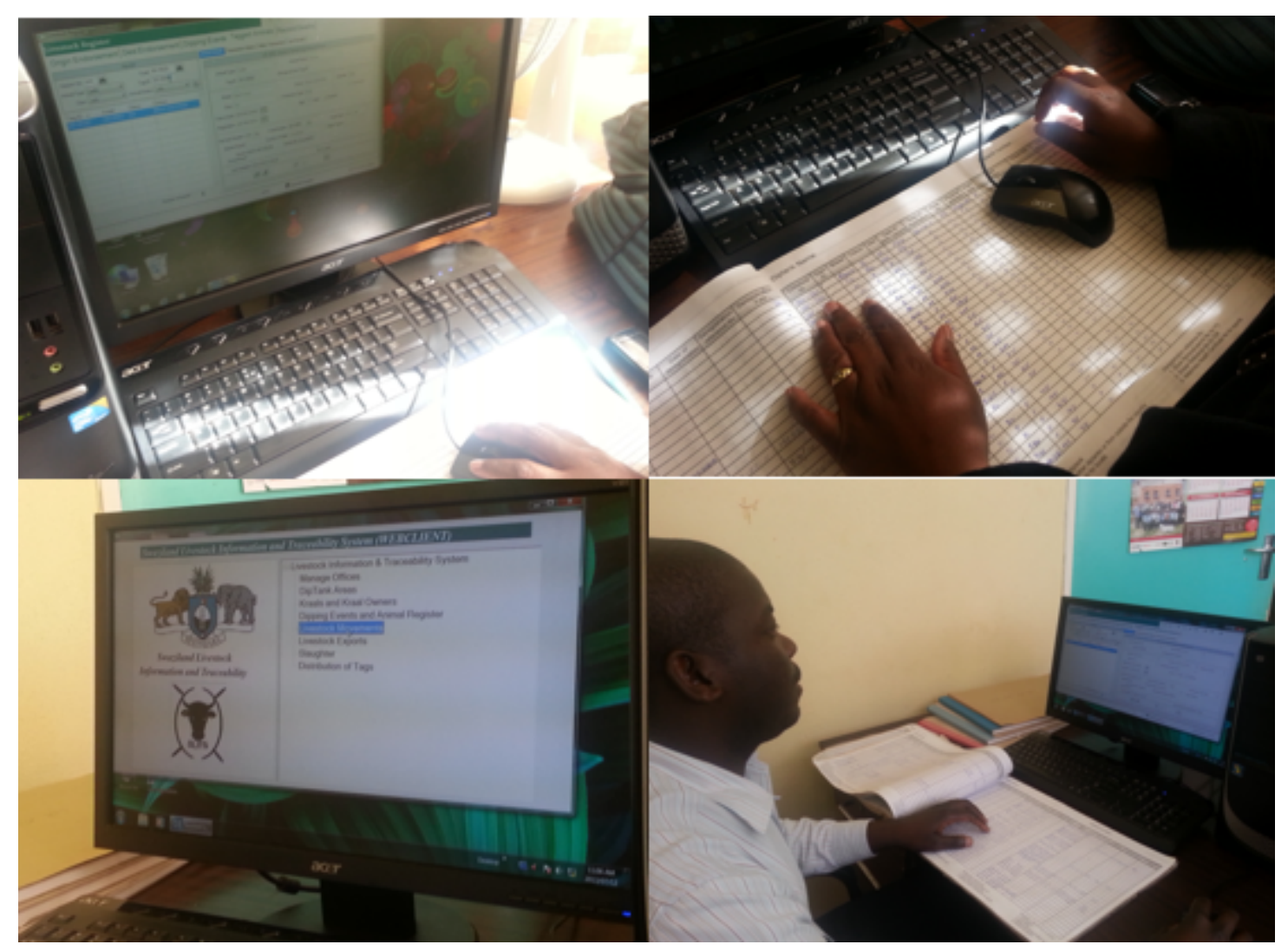

Figure 12. Photographs taken at a regional veterinary office to illustrate their use of SLITS on their computers on a typical Friday 


\section{Discussion of Interview 4 and 5}

Interview 4 and 5 contained the same questions, but were asked to two different roleplayers, one being the project manager of SLITS, and the other working at the Swazi Meat Industries. They were asked to answer questions relating to SLITS once it became fully operational. Both interviews took place on 7 August 2014. The interviews were approximately 20 minutes each.

During the two interviews the problems of implementing SLITS was addressed. Participant 7 elaborated on the fact that SMI buy the animals from feedlots and farmers, without a specific set price, but at a higher price than what the farmers are paid at the local abattoirs. SMI buy the meat when it becomes available, generally in large quantities in January and April, due to high availability, but when communal farmers want to sell their older animals, the SMI will not buy the animals to export their meat. Traceability is key, and from the beginning of 2014 the SMI could not buy any animal unless it had been captured on SLITS, and this resulted in fewer animals than in previous years becoming available for the export market.

Participant 8 , being in the project office, faced completely different obstacles, and encountered issues of how to capture animal movements effectively, work around insufficient infrastructure, how to keep everyone involved motivated and manage slow network technologies. The issues were based on the daily operations of SLITS. The issues included getting all the animals on the SLITS database, slow broadband, lack of funds to ensure that all the veterinary assistants were trained and lack of the necessary hardware infrastructure. It was not seen as long-term issues, but rather about how to ensure accurate transfer of information of cattle from the dip tanks to the SLITS database, and about enabling all communal farmers to be able to register their cattle. The teething problems experienced were addressed and it was believed that the problem would not persist.

It was further established that almost $75 \%$ of all cattle in the export chain originated from communal farms. Swaziland has a binding trade agreement to deliver 500 tons of beef to Norway, with less formal arrangements with other European countries, and no restrictions to export to South Africa. All meat is deboned before it is labelled and exported to Europe. The European market is a big incentive for the whole industry because there is market for lower-grade meat products too. Because the European market is so big, it takes meat for every purpose. If you sell an animal who is old and not as fat, there will be a market somewhere, which the Swazi's can sell to. 


\section{Concluding the Interviews}

The interviews express views from several different people involved in the process, from the initial comments of government officials, to a communal farmer managing a commercial farm, to how the veterinary assistants feel about the use and benefits of the system, finally discussing issues that the Meat Industries of Swaziland faced when traceability became mandatory and a drop in export numbers were felt, but with the project manager of SLITS, a member of government, who remains positive and continues to drive traceability to better the lives of the Swazi people. The interviews are subjective, with people talking very much about how they feel, what they experience and what changes they can tangibly see as SLITS was rolled-out country-wide. The Swazis took full ownership of the system and are proud to be an international exporter of meat products.

\section{Conclusion}

It is concluded that the introduction of SLITS benefitted all farmers, but specifically the communal farmers. This conclusion is based on the answers of the research questions:

1. The GDP increased as more cattle is exported. Refer to Figure 9.

2. Interviews with veterinary assistants working directly with the communal farmers and the representative of SMI indicated that the communal farmers received higher prices for their cattle, leading to an overall increase in GDP, higher dispensable income, which in turn grow entrepreneurs in rural areas.

3. The Government of the Kingdom of Swaziland's goals with the implementation of the livestock traceability system were met and benefitted the communal farmers in the following ways:

- Both communal and commercial farmers have larger access to export markets.

- Animals are uniquely identified and is recovered easier if lost or stolen, which in turn assists with a reduction in stock theft and ownership disputes.

- In cases of disease outbreaks, traceability assists in disease containment, as was the case with the foot-and-mouth disease outbreak of Namibia of 2015 (Author 1 \& Author 2, 2017).

- More animals are sold for export, increasing production.

- Government controlled movement permits are handled more efficiently.

Future research includes to expand the case study to other Southern African countries and to raise awareness under more developing countries of the socio-economic benefits of implementing livestock traceability systems. 


\section{References}

Aung, M. M., \& Chang, Y. S. (2014). Traceability in a food supply chain: Safety and quality perspectives. Food control, 39, 172-184.

Benbasat, I. (1984). "An analysis of research methodologies". The information systems research challenge, 47-85.

Bengis, R., Kock, R. \& Fischer, J. (2002). Infectious animal diseases: the wildlife/livestock interface. Revue Scientifique et Technique-Office international des épizooties, 21, 53-66.

Bonoma, T. V. (1985). "Case research in marketing: opportunities, problems, and a process". Journal of marketing research, 199-208.

Boudreau, T. (2010). "LIFT Swaziland Livelihood Data Analysis. FEG Analysis of Swaziland Livelihoods Data. Retrieved from http://www.feg-consulting.com/resource/reports/ FEG\%20Preassessment\%20livelihood\%20analysis\%20FINAL.pdf

Brown, L., \& Van der Ouderaa, F. (2007). Nutritional genomics: food industry applications from farm to fork. British journal of nutrition, 97(06), 1027-1035.

Cabrera, R., Cochran, M., Dangelmayr, L., \& D'Aguilar, G. (2010). African capacity building for meat exports: Lessons from the Namibian and Botswanan beef industries. Currents: Int'1 Trade LJ, 19, 55.

Central Bank of Swaziland. (2010). "Presentation on the Financial Sector in Swaziland". Retrieved from http://www.centralbank.org.sz/currency/index.php.

Central Bank of Swaziland. (2016). 2015/2016 Annual Report. Retrieved from http:// www.centralbank.org.sz/publications/annual/2015-2016.pdf

Commonwealth Local Government Forum. (2015). "The local government system in Swaziland: country profile". Retrieved from http://www.clgf.org.uk/default/assets/File/ Country_profiles/Swaziland.pdf

Corbin, J., \& Strauss, A. (2008). "Basics of qualitative research 3e": London: Sage.

Countries and their Cultures. (2016). "Swaziland". Retrieved from http:// www.everyculture.com/Sa-Th/Swaziland.html

Dlamini-Ndwandwe, N. F. (2011). "The Constitution and women's property rights in Swaziland. Southern African Public Law", 26(2), 408-430.

Dogliotti, S., García, M., Peluffo, S., Dieste, J., Pedemonte, A., Bacigalupe, G., Scarlato, M., Alliaume, F., Alvarez, J. \& Chiappe, M. (2014). Co-innovation of family farm systems: A systems approach to sustainable agriculture. Agricultural Systems, 126, 76-86.

Duffy, G., Lynch, O., \& Cagney, C. (2008). "Tracking emerging zoonotic pathogens from farm to fork". Meat Science, 78(1), 34-42.

Encyclopedia of the Nations. (2016). "Swaziland - Local government". Retrieved from http:// www.nationsencyclopedia.com/Africa/Swaziland-LOCAL-GOVERNMENT.html

Engelbrecht, J. (2012). Animal Identification and Traceability in Namibia: Farmers Support Program Veterinary Services and Farm Assured Namibian (FAN) Meat. Presentation made to farmers.

European Commission. (2002). Regulation (EC) No 178/2002 of the European Parliament and of the Council of 28 January 2002 laying down the general principles and requirements of food law, establishing the European Food Safety Authority and laying down 
procedures in matters of food safety. Official Journal of the European Communities L, $31,1-24$.

European Commission. (2006). Principles for traceability/product tracing as a tool within a food inspection and certification system. CAC/GL, 60 .

Herbert, R. K. (2007). "Swaziland. Countries and their cultures". Retrieved from http:// www.everyculture.com/Sa-Th/Swaziland.html

ISO 22000:2005. (2005). Food safety management systems -- Requirements for any organization in the food chain.

ISO/TS 22003:2007. (2007) Food safety management systems -- Requirements for bodies providing audit and certification of food safety management systems.

Kaplan, B., \& Maxwell, J. (2005). "Qualitative research methods for evaluating computer information systems. Evaluating the Organizational Impact of Healthcare Information Systems", 30-55.

Leitgeb, F., Funes-Monzote, F. R., Kummer, S., \& Vogl, C. R. (2011).” Contribution of farmers' experiments and innovations to Cuba's agricultural innovation system. Renewable Agriculture and Food Systems", FirstView, 1-14. Doi: 10.1017/S1742170511000251

Loureiro, M. L., \& Umberger, W. J. (2007). "A choice experiment model for beef: What US consumer responses tell us about relative preferences for food safety, country-of-origin labeling and traceability". Food Policy, 32(4), 496-514. Retrieved from http:// dx.doi.org/10.1016/j.foodpol.2006.11.006

Martinez, M. G., \& Poole, N. (2004). "The development of private fresh produce safety standards: implications for developing Mediterranean exporting countries". Food Policy, 29(3), 229-255.

Marumo, D., \& Monkhei, M. (2009). "The effects of the European Union (EU)-Imposed livestock identification and traceback system on Botswana's beef exports, revenue and rural poverty". Botswana Institute for Development Policy Analysis Gaborone, Botswana.

McGuire, S. (2015). "FAO, IFAD, and WFP. The State of Food Insecurity in the World 2015: Meeting the 2015 International Hunger Targets": Taking Stock of Uneven Progress. Rome: FAO, 2015. Advances in Nutrition: An International Review Journal, 6(5), 623-624.

Mdluli, S. (2012, 13 December 2012) "Discussing the use of SLITS". Interviewer: Author 1.

Mogensen, L., Nguyen, T., Madsen, N., Pontoppidan, O., Preda, T., \& Hermansen, J. E. (2015). "Environmental impact of beef-the food chain from farm to fork". Paper presented at the Annual Meeting of the European Association for Animal Production.

Population Reference Bureau. (2015). "2015 World Population Data Sheet”. Retrieved from http://www.prb.org/pdf15/2015-world-population-data-sheet eng.pdf

Prinsloo, T 1. (2017). "Livestock Traceability Systems in Swaziland and Namibia: Towards an Impact-for-Sustainable-Agriculture Framework". PhD Thesis: University of Pretoria.

Prinsloo, T \& De Villiers, C. (2017). "A Framework to Define the Impact of Sustainable ICT for Agriculture Projects: The Namibian Livestock Traceability System". EJISDC 82(6), 1 22.

Rich, K. M. \& Perry, B. D. (2011). Whither Commodity-based Trade? Development policy review, 29, 331-357. 
Roosen, J., Lusk, J. L., \& Fox, J. A. (2003). "Consumer demand for and attitudes toward alternative beef labeling strategies in France, Germany, and the UK". Agribusiness, 19(1), 77-90.

SAFA. (2003). South African feedlot industry and the economics of beef production. Unpublished document. South African Feedlot Association, Pretoria.

Scoones, I. \& Wolmer, W. (2003). Introduction: Livelihoods in Crisis: Challenges for Rural Development in Southern Africa. IDS Bulletin, 34, 1-14.

Scoones, I. \& Wolmer, W. (2006). Livestock, disease, trade and markets: policy choices for the livestock sector in Africa.

Smith, G., Pendell, D., Tatum, J., Belk, K. \& Sofos, J. (2008). Post-slaughter traceability. Meat Science, 80, 66-74.

Sodano, V., \& Verneau, F. (2004). "Traceability and food safety: public choice and private incentives. Quality Assurance, Risk Management and Environmental Control in Agriculture and Food Supply Networks", Universitat Bonn-ILB, Germany.

The Government of the Kingdom of Swaziland. (2012). "Veterinary Services: The Swaziland Livestock Information and Traceability System. Ministry of Agriculture". Retrieved from ht tp://Ww w.gov.sz/index.php? option $=$ com content $\&$ view $=$ article $\&$ catid $=80 \% 3$ Aagriculture $\&$ id $=865 \% 3$ Aslits $\&$ Itemi $\underline{\mathrm{d}=594}$

The International Fund for Agricultural Development. (2013). "Enabling the rural poor to overcome poverty in Swaziland". Retrieved from https:/www.ifad.org/documents/ $\underline{10180 / 66 b 37 d d b-b e 5 b-4824-a 23 c-47 c b 102 c 5 c c 7}$

Thornton, P. K., Jones, P. G., Ericksen, P. J., \& Challinor, A. J. (2011). “Agriculture and food systems in sub-Saharan Africa in a $4 \mathrm{C}+$ world". Philosophical Transactions of the Royal Society of London A: Mathematical, Physical and Engineering Sciences, 369(1934), 117-136.

Toldrá, F. \& Reig, M. (2006). Methods for rapid detection of chemical and veterinary drug residues in animal foods. Trends in Food Science \& Technology, 17, 482-489.

United Nations. (2015).”The Millennium Development Goals report 2015”. Retrieved from http://www.un.org/millenniumgoals/2015_MDG_Report/pdf/ MDG\%202015\%20rev\%20(July\%201).pdf.

Vallett, B. (2013). "Animal identification and product traceability from the farm to the fork must be progressively implemented worldwide". Editorial from the OIE Director General (April 4, 2008). Retrieved from http://www.oie.int/eng/edito/en_lastedito.htm

Vandome, C., Vines, A., \& Weimer, M. (2013). "Swaziland: Southern Africa's Forgotten Crisis": Chatham House London.

Van Zyl, E., Mccrindle, C. \& Grace, D. (2008). Participatory risk assessment for food safety in informal markets. 54th International Congress of Meat Science and Technology, 2008. $10-15$.

Vosloo, W., Bastos, A., Sangare, O., Hargreaves, S. \& Thomson, G. (2002). Review of the status and control of foot and mouth disease in sub-Saharan Africa. Revue Scientifique et Technique-Office International des Epizooties, 21, 437-445.

Weiss, B. (2012). "Configuring the authentic value of real food: Farm-to-fork, snout-to-tail, and local food movements". American Ethnologist, 39(3), 614-626.

Wik, M., Pingali, P., \& Broca, S. (2008)." Global agricultural performance: past trends and future prospects". Background paper for the WDR. 
Williams, J. (2017). "The impact on SLITS on the communal farmer since 2013". Interviewer: Author 1.

World Bank. (2007). "World Development Report 2008: Agriculture for Development”. New York: Oxford University Press.

Yin, R. K. (1994). "Case study research: Design and methods": Beverley Hills: Sage publishing. 